talvolta non sono ben definibili, con il risultato che troppo spesso dobbiamo assistere alla creazione di taxa superflui.

\section{BIBLIOGRAFIA}

COCHET, S., -1977- Les Myxomycètes de France. Bull. Soc. Myc. Fr. 93 (3): 159-200.

ELIASSON, U. \& N. LUNDQVIST -1979- Fimicolous Myxomycetes. Bot. Not. 132: 551-568.

GØTZSCHE, H.F. -1989- Myxomycetes from Greenland. Opera Botanica 100: 93-103.
MARTIN, G.W. \& C.J. ALEXOPOULOS -1969The Myxomycetes. Univ. Iowa Press.

Aceptado para su publicación en Enero de 1998

Dirección de los autores. G. Cacialli: via Aloisi 3, 57128 Livorno (Italia). V. Caroti: via Zola 51, 57122 Livorno (Italia). F. Doveri: via Baciocchi 9, 57126 Livorno (Italia).

\title{
69. GIGASPERMUM MOURETII CORB. (GIGASPERMACEAE, MUSCI), A NEW SPECIES FROM ITALY
}

\section{Alfredo CARRATELLO \& Michele ALEFFI}

Gigaspermum mouretii Corb. (Gigaspermaceae, Musci), una nueva especie para Italia

Key words. Musci, Gigaspermum, Italy.

Palabras clave. Musci, Gigaspermum, Italia.

During a series of studies conducted in north-western Sicily in October 1996, Gigaspermum mouretii Corb. was gathered by A. Carratello in the periphery of the inhabited center of the municipality of Capaci (Palermo) (3810'93" N, 1314'28”E). The species was found on a small piece of land (about $200 \mathrm{~m}^{2}$ ) once used for pasture, at about $50 \mathrm{~m}$ from the sea and at $5 \mathrm{~m}$ a.s.l., with $\mathrm{N}-\mathrm{NW}$ exposure.

Its leaves are evenly spaced or crowded, almost orbicular, apiculate, concave and 0.7 $\mathrm{mm}$ long (without the apiculus) (fig. 1). Its margin is flat, smooth and somewhat crenulate in the upper part. Nerves are absent. Cells in the basal part of the leaf are rectangular with smooth walls; in the median and upper part they are often partly hyaline, irregular to rhombic. The perichaetial leaves are hyaline, green at the base, extending $2.5 \mathrm{~mm}$ long; they are elongate-triangular, longly acuminate and strongly concave, enclosing the whole capsule. The margin is flat, smooth in the lower half and slightly denticulate in the upper half. Its capsule is sessile, gymnostomous, with a wide, slightly 


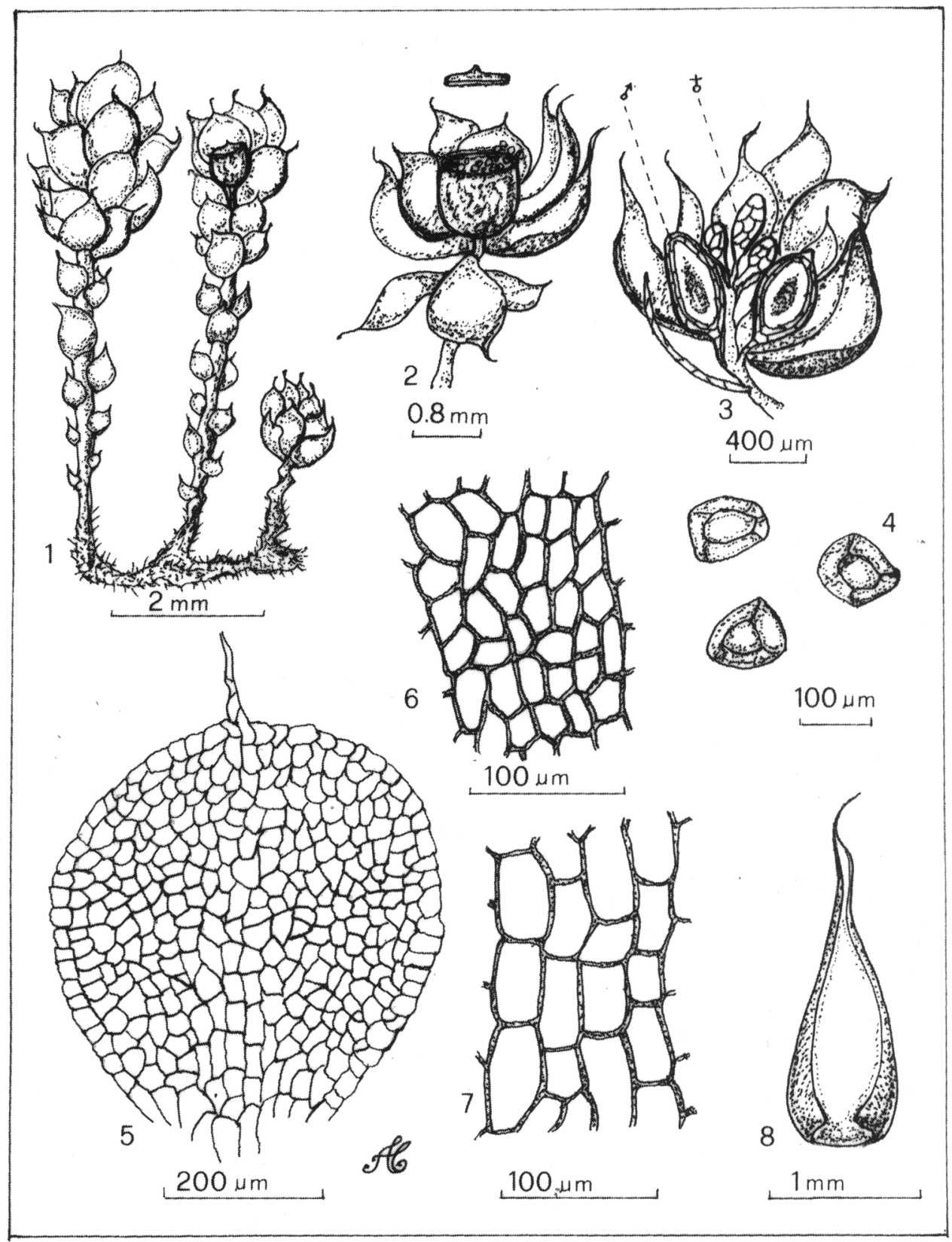

Figure 1. Gigaspermum mouretii Corb. 1: mature plant (a), mature plant with sporophyte (b), sterile plant (c); 2: gametophyte with capsule; 3: stem showing young archegonia (at apex) and antheridia (below); 4: spores; 5 : mature leaf; 6 : median cells of mature leaf; 7: basal cells of mature leaf; 8: perichaetial leaf. (Des. by A. Carratello). 


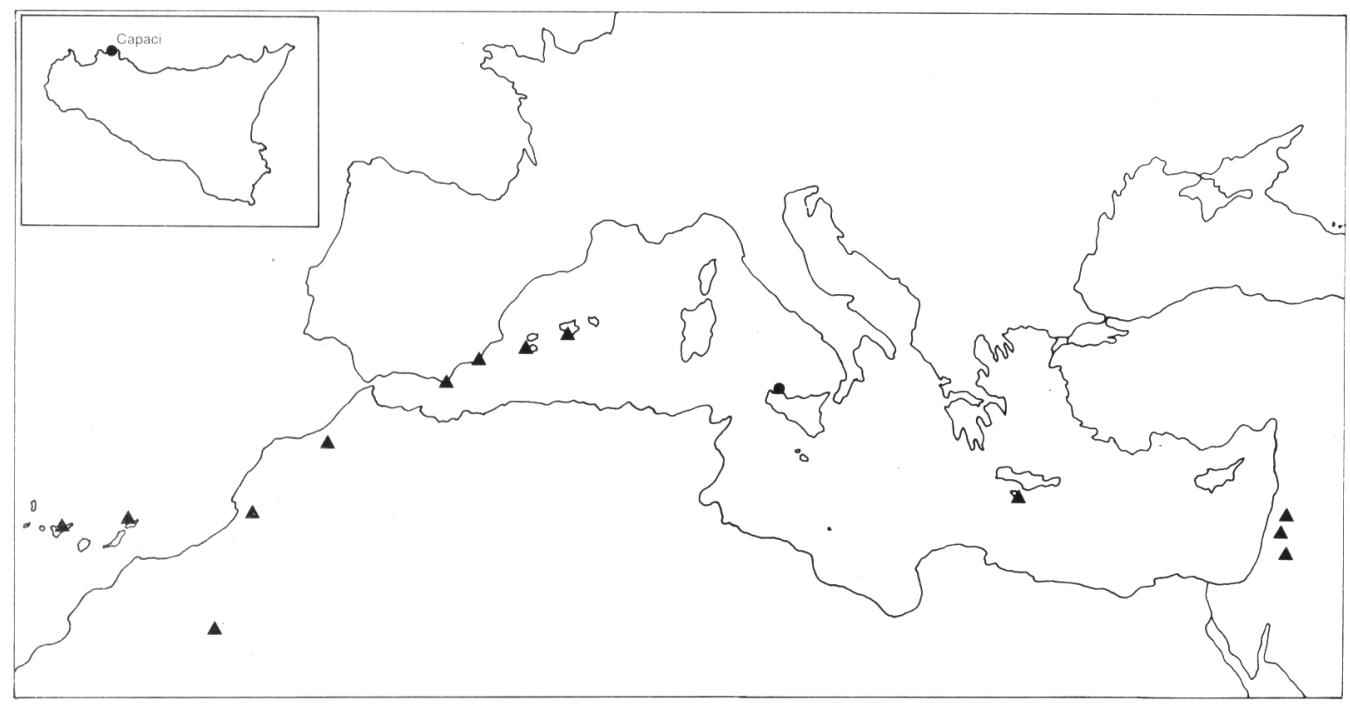

Figure 2. Distribution of Gigaspermum mouretii. The dot represents the new sitings for Italy.

convex operculum and a minute calyptra, on a short seta shimmering through the semitransparent perichaetial leaves. The spores are polyhedric, very large (ca. $130 \mu \mathrm{m})$, brownish, almost smooth.

All the plants were fertile and the sporophytes were found in abundance. The arrangement of the gametangia was paroicous (antheridia in leaf axils, just beneath the archegonia). This species is distinguished by its thick, hyaline, subterranean, rhizomatous, fragile stems and short gametophores resembling buds.

In the Capaci area Gigaspermum mouretii grows on a shallow argillaceous-calcareous substratum with rocky outcroppings, where it forms dense gray-green tufts. The species is associated with Bryum caespiticium Hedw., Didymodon vinealis (Brid.) R.H. Zander, Fissidens viridulus (Sw.) Wahlenb., Funaria muhlenbergii Turner, Pottia starckeana (Hedw.) Müll. Hal., Tortella nitida (Lindb.) Broth., Trichostomum crispulum Bruch,
Fossombronia caespitiformis De Not. ex Rabenh., F. husnotii Corb. and $F$. wondraczekii (Corda) Dumort. ex Lindb. All the specimens are deposited in the herbaria of the Universities of Palermo [PAL] and Camerino [CAME].

Gigaspermum mouretii is a rare oceanicmediterranean species (Schumacker \& Martiny, 1995). Its first description, by Corbière (1913), was for a specimen from Morocco. Later Heim gathered it in 1934 and Jelenc reported it in 1955 in two other localities of Morocco. The first report for the European continent was by Allorge \& Casas (1958) in the Sierra del Cabo de Gata (Spain). It was later found in other sites in Spain by Acuña et al. (1974), by Ros (1984), Ros \& Guerra (1987) and by Roselló in the Balearic islands of Mallorca and Formentera (Casas et al., 1985). More recent finding were by Malme (1988) in the Canary islands, by Dirkse \& Bouman (1990) in Lanzerote and in Tenerife and by Urmi in Crete (Gávdhos Island, near Kastri, Nomos Khanion, leg. E. Urmi 1983, $\mathrm{Z})$. The species is known in several sites in Israel 
(Herrnstadt et al., 1980, 1991). The report of Gigaspermum mouretii for Capaci is the first for Italy and extends the species' areal of distribution in the Mediterranean basin (fig. 2).

In most of these locations the species was always found sterile, a condition which should be related to the fierce aridity of the collection sites. It is known that in certain regions with dry climates, the moss flora mainly consists of sterile plants. In 1980, sporophytes of Gigaspermum mouretii were found in abundance in one locality of Israel where collections made in previous years had no sporophytes. The unusual winter of 1970-80 had a long and continuous moist period and probably allowed unusual sporophyte development (Hernnstadt et al., 1980).

In the Capaci site Gigaspermum mouretii was gathered with sporophytes in SeptemberOctober with the first autumnal rains. The area's climate, though it has typically mediterranean characteristics, presents an average annual rainfall of about $700 \mathrm{~mm}$, with average monthly temperatures above $10^{\circ} \mathrm{C}$ which, in the period from May to September, exceed $20^{\circ} \mathrm{C}$. A series of mountainous reliefs immediately inland greatly attenuates the impact of the hot African winds and in fact blocks the establishment of a decidedly arid climate. Only the presence of a not particularly arid climate, characterized by a moderate gradient of humidity seems to be the basis for this species' sporification.

Gigaspermum mouretii is also of interest from the phytogeographic point of view.

All the species of this genus are distributed in the Southern Hemisphere (southern Africa, Madagascar, Australia, Tasmania and New Zealand); Gigaspermum mouretii, on the other hand, has a mediterranean distribution and thus represents a very important boreo-austral disjunction (Allorge, 1931; Casas et al., 1981).

Some hypotheses can be advanced to explain the finding of Gigaspermum mouretii in the Capaci area.
First, the spores could have been carried by the hot African winds full of sand which periodically blow over the zone and stop near the mountainous reliefs which surround the Capaci basin.

Second, the spores may have been dispersed by the air traffic and tourism which arrives in the zone through the nearby Palermo airport, from Spain, the Canary Islands and from the nearby African countries.

Further research to identify new Gigaspermum mouretii sites has so far failed and seems to confirm for the moment these hypotheses.

AKNOWLEDGMENTS. We are grateful to C. Sérgio (Lisbon) for the determination of the specimen of Gigaspermum mouretii.

\section{REFERENCES}

ACUÑA, A., C. CASAS, M. COSTA, E. FUERTES, M. LADERO, M.L. LOPEZ, R.M. SIMO \& J. VARO -1974-Aportaciones al conocimiento de la flora briológica española. Nótula I: El Cabo de Gata (Almería). Anales Inst. Bot. Cavanilles 31 (2): 59-95.

ALLORGE, P. -1931- Sur quelques types de disjonctions dans la flore muscinale ibérique. Trav. Cryptog. L. Manguin 465-475.

ALLORGE, V. \& C. CASAS DE PUIG -1958Contribution à la flore bryologique de l'Espagne. Rev. Bryol. Lichénol 27 (1-2): 55-65.

CASAS, C., M. BRUGUÉS \& R.M. CROS -1981Contribució al coneixement de l'àrea geogràfica d'alguns briòfits. Treb. Inst. Catalana Hist. Nat. 9: 169-178.

CASAS, C., M. BRUGUÉS, R.M. CROS \& C. SÉRGIO - 1985- Cartografia de Briòfits. Península Ibèrica i les Illes Balears, Canàries, Açores i Medeira. Inst. Estudis Catalans I: 1-50.

CORBIÈRE, L. -1913- Contribution à la flore bryologique du Maroc d'après les récoltes du Lieutenant Mouret. Rev. Bryol. 40 (1): 7-16.

DIRKSE, G.M. \& A.C. BOUMAN - 1990-Additions to the bryophyte flora of the Canary Islands. Lindbergia 15: 145-150. 
DÜLL, R. -1992- Distribution of the European and Macaronesian Mosses (Bryophytina). Annotations and Progress. Bryol. Beitr. 8/9: 1-223.

HERRNSTADT, I., C.C. HEYN \& M.R. CROSBY 1980- New Data on the Moss Genus Gigaspermum. Bryologist 83: 536-541.

HERRNSTADT, I., C.C. HEYN \& M.R. CROSBY 1991- A Checklist of the Mosses of Israel. Bryologist 94 (2): 168-178.

JELENC, F. - 1955-Muscinées de l'A frique du Nord. Bull. Soc. Géogr. Archéol. Oran. (Extrait de 125 pp.).

MALME, L. - 1988- Distribution of bryophytes on Fuerteventura and Lanzarote, the Canary Islands. Sommerfeltia 7: 1-54.

ROS, R.M. -1984- Una nueva localidad de Gigaspermum mouretii Corb. (Musci) en la Peninsula Iberica. Acta Bot. Malacitana 9: 93-96.
ROS, R.M. \& J. GUERRA -1987- Catálogo de briófitos terrícolas de la Región de Murcia (SE de España). Candollea 42 (2): 577-599.

SCHUMACKER, R. \& Ph. MARTINY -1995Threatened bryophytes in Europe including Macaronesia. In: European Committee for Conservation of Bryophytes (ed.): Red Data Book of European Bryophytes 2: 31-193.

Aceptado para su publicación en Septiembre de 1998

Dirección de los autores. A. CARRATELLO: Dipartimento di Scienze Botaniche, Università di Palermo, Via Archirafi 38, 90123 Palermo, Italia. M. ALEFFI: Dipartimento di Botanica ed Ecologia, Università di Camerino, Via Pontoni 5, 62032 Camerino (MC), Italia.

\section{ADICIONES A LA FLORA VASCULAR DE MURCIA.}

\section{Pedro SÁNCHEZ GÓMEZ, Ernesto COY, Antonio Félix CARRILLO, Antonio HERNÁNDEZ y Miguel Angel CARRIÓN.}

New records for the Vascular Flora of Murcia

Palabras claves: flora vascular, corología, Murcia (España).

Key words: vascular flora, corology, Murcia (Spain).

Como resultado de las prospeciones realizadas en los últimos meses, se han detectado diversas especies de interés que pasan a engrosar o matizar el catálogo incluido en Flora de Murcia (cf. Sánchez Gómez et al, 1998).
Mentha pulegium L.

Hs, *MURCIA: Mula, Puerto del Agüica, 30SXH2713, $450 \mathrm{~m}$, prados temporalmente inundados, 12-VI-1998, P. Sánchez Gómez, A.F. Carrillo \& M.A. Carrión. MGC 46818.

Aunque con anterioridad ya había sido citada en diversas partes de Murcia (cf. Alcaraz et al., 1989) 